\title{
Effects of a Preventive Intervention of Emotional Regulation in the School Context
}

\author{
Nathalia Santos da Costa Vieira, ${ }^{1, *}$ (D), Zilda Aparecida Pereira Del Prette ${ }^{2}$ (D), \\ Amanda Margarida Oliveira ${ }^{1}$ (D), Denise Fabiane Ribeiro ${ }^{1}$ (1), Samantha Fernandes Silva ${ }^{3}$ (D), \\ Eder Moreira Raimundo ${ }^{3}$ (D, Sofia Carvalho Teodoro ${ }^{1}$ (D, Lucas Cordeiro Freitas ${ }^{2}$ (D), \\ \& Leonor Bezerra Guerra ${ }^{1}$ (D) \\ ${ }^{1}$ Universidade Federal de Minas Gerais, Belo Horizonte, MG, Brazil \\ ${ }^{2}$ Universidade Federal de São Carlos, São Carlos, SP, Brazil \\ ${ }^{3}$ Pontificia Universidade Católica de Minas Gerais, Belo Horizonte, MG, Brazil
}

\begin{abstract}
In early childhood education, socio-emotional learning is not always considered with appropriate planning nor based on scientific evidence. Aiming to analyze impact of an Emotional Regulation (ER) Intervention in school achievement and social skills (SS), fifty-five children from public schools were evaluated by Raven's Coloured Progressive Matrices (CPM), School Achievement Test (TDE) and Social Skills Rating System (SSRS-BR). After nine 50-minute meetings addressing ER strategies, evaluation of SS by the teacher indicated improvement in all aspects of SS in Intervention Group (IG) and worsening of the self-control in Comparison Group (CG). Self-evaluation of SS showed that IG overcame the initial difference in assertiveness and problem avoidance. Results suggest that ER programs can bring benefits to the development of SS.
\end{abstract}

KEYWORDS: emotional regulation, preventive intervention, social skills, school achievement, academic competence

\section{Efeitos de uma Intervenção Preventiva em Regulação Emocional no Contexto Escolar}

\begin{abstract}
RESUMO - Aprendizagem socioemocional nem sempre é contemplada, com devido planejamento e embasamento científico, na educação infantil. Avaliou-se impacto de intervenção de Regulação Emocional (RE) no desempenho escolar e Habilidades Sociais (HS) de 55 crianças de escolas públicas, utilizando-se Matrizes Progressivas Coloridas de Raven (CPM), Teste de Desempenho Escolar e Sistema de Avaliação de Habilidades Sociais (SSRS-BR).Após nove encontros de 50 minutos abordando estratégias de RE, avaliação de HS pelo professor indicou melhora em todos os aspectos de HS noGrupo Intervenção (GI) e piora no autocontrole no GrupoComparação (GC). Autoavaliação de HS mostrou que GI superou diferença inicial na assertividadee evitação de problemas. Os resultados sugerem que programas de RE podem trazer benefícios para o desenvolvimento das HS.
\end{abstract}

PALAVRAS-CHAVES: regulação emocional, intervenção preventiva, habilidades sociais, desempenho acadêmico, competência acadêmica

\section{INTRODUCTION}

The interest in developing and evaluating preventive interventions in educational context has been encouraged by the World Health Organization since 1999, when it proposed the inclusion of preventive practice related to

*E-mail: nathysantos@gmail.com

- Submetido: 04/03/2017; Revisado: 20/12/2019; Aceito: 25/03/2020. 
general child's development, aiming a reduction of risk behavior and promotion of self-esteem and self-confidence through social skills (SS)(World Health Organization, 2003).

Many studies (Bywater et al., 2011; Domitrovich et al., 2017; Domitrovich \& Greenberg, 2000; Faria et al., 2013; Hawkins et al., 2008; Izard et al., 2002; Lawson et al., 2018; Riggs et al., 2006; Wyman et al., 2010) have focused on preventive intervention programmes that help educational institutions to fulfill the wide role given to them which is to guarantee the emotional and social positive development, promoting individual's formation and socialization (Riquelme \& Munita, 2011). In this way, studies opt for socio-cognitive development programs in the beginning of childhood, justifying that pro-social children with strong family and school bonds define a positive developmental trajectory and with smaller rates of health risk behaviors (Hawkins et al., 2008).

The Collaborative for Academic, Social, and Emotional Learning (CASEL, 2013) "was formed in 1994 with the goal of establishing high-quality, evidence-based social and emotional learning (SEL) as an essential part of preschool through high school education"(CASEL, n.d, p. 1).These SEL pioneers came together to address a concern about ineffective school programming. They support educators and policy leaders in the relevant task of implementing emotional and social learning programs, since these skills are crucial in several contexts of the individual's life such as educational, citizenry and work.

The Differential Emotions Theory (DET) corroborates the importance given to emotional learning by pointing out the critical role emotions have on the motivation of social and individual behaviors for adaptation, especially when they involve the interaction between the individual and the social environment (Izard et al., 2002). CASEL (2013) shows that social and emotional skills training facilitates the supportive relationships in educational contexts in a way that learning acquires a challenging, interesting, and meaningful nature.

Emotion is a focus of studies since it is a basic and guiding aspect in a person's relationship with the environment on searching for a better adaptation (Damasio, 2011; Gross, 2007; Izard et al., 2002; Martin \& Ochsner, 2016). Emotional regulation (ER) refers to processes involved in dealing with high levels of positive and negative emotions (Kopp, 1989) what makes one "use conscious and unconscious strategies to keep, increase or decrease one or more components of the emotional response" (Mocaiber et al., 2008, p. 532). The ER presumes ability to experience and express emotions, and influences the types of emotions a person has, aiming for better quality in social relationships.

It is well known that "knowing your own emotions and knowing how to deal with them is a crucial part in interpersonal development and a critical component of social competence in practically all situations and demands that take place in daily life" (Del Prette \& Del Prette, 2011, p. 121). The SS constructs visibly associated to ER, since understanding and managing one's own emotions and the emotions of others are determinants of the quality of relationships in social environment. It is expected that, by achieving the adaptive quality of emotions, this will reflect on aspects of SS, improving the individual's social context, so the effect can be generalized to other aspects of behavior, learning and mental health.

SS correlate with relevant factors on initial phases of child's development, such as: a) communication; b) initiation and maintenance of positive social relationships; c) acceptance by colleagues; d) satisfactory schooling adjustment; e) learning; f) questioning and requesting for help; g) satisfaction of needs in an appropriate way; h) protection of the individual on his/her socialization (Del Prette \& Del Prette, 2009; Dowd \& Tierney, 2005; Taylor et al., 2017). SS are considered a "protective factor for a satisfactory developmental trajectory" (Del Prette \& Del Prette, 2005 as cited in Rodrigues et al., 2010, p.833). According to these authors, good development of SS in childhood can facilitate the adjustment to educational context and favor pupil's mental health. On the other hand, the lack of development in SS can limit the access to educational and social opportunities.

The period around 6 years-old is decisive to development of SS and ER. This development depends on maturation of nervous system areas, stimulation and environmental conditions. In this phase a fast increase in the number and variety of connections between brain areas related to emotions and cognition is noticed, which enables the processes of self-concept and self-regulation. At this age, due to entrance in educational context, child's emotions and behaviors become more related to the interaction with peers and less supervised by adults. There is an increase in both positive and negative emotional experiences outside the family circle, which are associated especially to feedback on social and academic competences expressed by the child. This way, the child improves the ability to communicate emotions and to be aware of them. This awareness will enable the child to use cognitive techniques to modulate his/her emotions (Izard et al., 2002).

The beginning of formal schooling is a moment of big challenges and accomplishments in human development, and it can be considered a receptive period for development of ER and SS. As these abilities are learnable, it is justifiable to use interventions that work opportunely in a brain still in development, aiming to protect the individual being formed and to provide educational improvements (Shonkoff, 2011).

In Brazil, there are 48.5 million students enrolled in Basic Education, of which 39.5 million are in public schools. Education is compulsory from the age of 4 to 17 years-old, starting with Early Childhood Education, followed by Elementary Education, which includes $56 \%$ of students, 
from the age of 6 to 14 years-old, lasting nine years and, after that, High School with duration of three years. Early Childhood Education, aimed at children aged 4 to 5 years old, had $93 \%$ of children enrolled in 2017. In 2018, 99.3\% of young people aged 6 to 14 years old were in Elementary School, with $98 \%$ enrolled in the year/grade corresponding to their age. Regarding High School, $91.5 \%$ of young people aged 15 to 17 were in school, but only $68.7 \%$ enrolled in the year/grade corresponding to their age (Todos pela Educação, 2019).

The National Common Curricular Base (Base Nacional Comum Curricular - BNCC) recognizes that students must be given the opportunity and the means for a training that considers the various aspects, physical, emotional, affective, social and cognitive, of development (Ministério da Educação, 2018). However, there are still no public policies that indicate specific strategies or programs for the development of social skills and emotional regulation. It is the school responsibility to plan how these skills will be developed. Although there is literature on social and emotional skills to inspire schools (Chernyshenko et al., 2018), the use of programs based on scientific evidence obtained from the Brazilian population could contribute to the broader and more effective implementation of the BNCC's proposals (Ministério da Educação, 2018).

This study aimed to evaluate the impact of an intervention focused on ER on school performance and on SS of children that are beginning the formal schooling.

\section{METHOD AND DESIGN}

This study was approved by the Ethics Committee in Research of Universidade Federal de Minas Gerais (CEP/ UFMG N ${ }^{\circ}$. 186.711) and was performed in accordance with ethical standards, meeting all the requirements of Resolution n. 196 , October $10^{\text {th }}, 1996$ of National Council of Health, which regulates the research with human beings. Informed Consent Forms (ICF), signed by children, their parents and teachers, were obtained from all individual participants included in the study.

The study was performed in two municipal elementary schools in Belo Horizonte, Minas Gerais, Brazil. It followed a quasi-experimental design. There was no random distribution in the groups due to the fact that it was developed in the schooling context, which already has its own subject organization and enables ecological validity. In order to ensure validation of the research the Municipal Board of Education indicated schools presenting similar profiles related to: results in standardized tests used for the education evaluation index 1; socio-economical or racial distribution; socio-economic index; percentage of students who were beneficiary of social assistance income transferring programs; and percentage of students with disabilities.

Crossing these data provides the study with two institutions that serve relatively homogeneous populations and offer an approximate standard of services, allowing the groups to be compared to be composed of participants with similar profiles.

The research design comprises this phases: (1) Partnership with the Municipal Department of Education to point two schools with similar profiles; (2) Schools were invited to participate in the study and received the Consent Letter, being informed of the purpose, method, procedures

1 The evaluation indexes were crossed using Avalia-BH (http://www. avaliabh.caedufjf.net/diagnosticabh), PROALFA/SIMAVE (https://www. educacao.mg.gov.br/politica-de-privacidade/page/15115-simave) and Educacenso (http://portal.mec.gov.br/index.php?Itemid=339). and ethical aspects of the study; (3) Upon acceptance from the school, first-year teachers were also informed about the research and invited to participate by signing the Informed Consent Form; (4) A meeting was held with the students' parents whose teachers agreed to participate in the study to clarify the purpose, method, procedures and ethical aspects. In this occasion the Informed Consent Form was signed by the parents or guardians of children over 7 years; (5) $1^{\text {st }}$ evaluation of all 55 students from both schools, at the beginning of the study, by means of Socioeconomic and Cultural Questionnaire, Raven's Coloured Progressive Matrices, School Achievement Test and Social Skills Rating System; (6) Teacher training about emotional regulation in both schools; (7) Intervention focused on ER involving children and their teachers in just one of the schools (Intervention Group); (8) $2^{\text {nd }}$ evaluation of children from both schools (Intervention and Comparison Groups), two months after the end of intervention, by means of School Achievement Test and Social Skills Rating System.

\section{Participants}

This study was performed on 55 (29 males, 26 females) elementary students in the $1^{\text {st }}$ grade, aged 6 to 7 years, and their teachers. Inclusion criteria were the children enrolled in $1^{\text {st }}$ grade and Informed Consent Forms (ICF) signed by children, their parents and teachers. The invitation to participate in study was extensive to all students of $1^{\text {st }}$ grade in classrooms of both schools whose teachers agreed to collaborate with this research. Then, the sample was constituted according to convenience. Exclusion criteria were non-compatible age to school grade and percentile below 25 on the Raven's Coloured Progressive Matrices test, indicating intellectual capacity below average.

Children $(n=21)$ from three different classrooms of one school constituted the Intervention Group (IG) and were submitted to intervention focused on emotional regulation. 
The Comparison Group (CG) consisted of children $(n=34)$ from three different classrooms of the other school and were not submitted to intervention. Throughout the research three children abandoned the project due to change of school shift or educational institution.

The characterization of the sample indicated similarity between the groups, the only significant difference pointed out was in the parents' relationship (Table 1).

Concerning intellectual level, as rated by Raven's Coloured Progressive Matrices, there was no significant difference between children of both schools, and $60 \%$ of the evaluated children had results above average; $36.4 \%$ were average and $3.6 \%$ below average.

Teachers who contributed to the research are all female and have higher education. GC teachers $(n=4)$, aged 46 to 51 , were all pedagogues, one of them also had a complementary education in history, all of them having professional practice in classroom for more than $15(n=1)$ or $20(n=3)$ years. GI teachers $(n=6)$, aged 33 to 51, were graduated in Pedagogy $(n=3)$, History $(n=1)$ and Liberal Arts $(n=1)$, all of them having professional practice in classroom for more than 11 $(n=1)$, between 11-15 $(n=2)$ and for more than $21(n=3)$ years.

Table 1

Comparison of socioeconomic and cultural characteristics of students submitted (IG) or non-submitted (CG) to the intervention focused on ER

\begin{tabular}{|c|c|c|c|}
\hline & \multicolumn{2}{|c|}{ Groups } & \multirow{2}{*}{$\mathbf{P}$} \\
\hline & GI $(n=21)$ & GC $(n=34)$ & \\
\hline Gender & & & $0.284 *$ \\
\hline Male & $13(61.9 \%)$ & $16(47.1 \%)$ & \\
\hline Female & $8(38.1 \%)$ & $18(52.9 \%)$ & \\
\hline Child's Age & $6.5 \pm 0.5$ & $6.7 \pm 0.5$ & $0.262 * * *$ \\
\hline Age at which child went to school & $2.6 \pm 1.2$ & $2.5 \pm 1.2$ & $0.844 * * *$ \\
\hline Age of the guardian & $36.5 \pm 6.0$ & $36.5 \pm 5.4$ & $0.958 * * *$ \\
\hline Parents relationship & & & $0.039 * *$ \\
\hline Marriage/Civil Partnership & $16(76.2 \%)$ & $19(55.9 \%)$ & \\
\hline Dating & $1(4.8 \%)$ & $0(0.0 \%)$ & \\
\hline Separated/divorced & $2(9.5 \%)$ & $13(38.2 \%)$ & \\
\hline Unrecognized father & $1(4.8 \%)$ & $0(0.0 \%)$ & \\
\hline Widow & $1(4.8 \%)$ & $2(5.9 \%)$ & \\
\hline Age of the guardian & $36.5 \pm 6.0$ & $36.5 \pm 5.4$ & $0.958 * * *$ \\
\hline Number of siblings and half-siblings & $1.1 \pm 1.2$ & $0.9 \pm 1.2$ & $0.420 * * *$ \\
\hline Family income & & & $0.139 * *$ \\
\hline up to 2 minimum wages & $7(35.0 \%)$ & $6(19.4 \%)$ & \\
\hline 2-5 minimum wages & $11(55.0 \%)$ & $15(48.4 \%)$ & \\
\hline More than 5 wages & $2(10.0 \%)$ & $10(32.3 \%)$ & \\
\hline Father's education & & & $0.547^{*}$ \\
\hline Elementary school & $7(33.3 \%)$ & $7(21.9 \%)$ & \\
\hline High school & $7(33.3 \%)$ & $15(46.9 \%$ & \\
\hline College & $7(33.3 \%)$ & $10(313 \%)$ & \\
\hline Mother's education & & & $1.000 * *$ \\
\hline Elementary school & $3(14.3 \%)$ & $4(12.1 \%)$ & \\
\hline High school & $11(52.4 \%)$ & $17(51.5 \%)$ & \\
\hline College & $7(33.3 \%)$ & $12(36.4 \%)$ & \\
\hline Family atmosphere & & & $0.055^{* *}$ \\
\hline Harmonious & $5(23.8 \%)$ & $18(52.9 \%)$ & \\
\hline Good most of the time & $11(52.4 \%)$ & $9(26.5 \%)$ & \\
\hline Satisfactory & $2(9.5 \%)$ & $6(17.6 \%)$ & \\
\hline A little troubled & $1(4.8 \%)$ & $1(2.9 \%)$ & \\
\hline Very troubled & $1(4.8 \%)$ & $0(0.0 \%)$ & \\
\hline Violent & $1(4.8 \%)$ & $0(0.0 \%)$ & \\
\hline
\end{tabular}

Note. "Comparison between IG and CG (Chi-Square Test) ${ }^{* *}$ Comparison between IG and CG ( Fisher) Test)

***Comparison between IG and CG(Mann-Whitney Test) 


\section{Instruments}

\section{Screening instruments}

Socioeconomic and Cultural Questionnaire (Lasaitis, 2009) was answered by parents, collecting information about the children, family structure and relationship within the family organization; parents level of schooling; economic level and ethnicity.

Raven's Coloured Progressive Matrices- CPM, for children (Angelini et al., 1999) a non-verbal intelligence test. The Brazilian normative study was performed by Angelini et al. (1999), considering the test valid and precise. Jacquemin and Xavier (1982/1984 as cited in Bandeira et al., 2004) found a 0.90 total reliability coefficient through the split-half method and applying the Spearman-Brown correction.

\section{Instruments used for evaluation prior to and after the emotional regulation intervention}

School Achievement Test [Teste do Desempenho Escolar] (Stein, 1994), a standardized Brazilian instrument which consists of three sub-tests evaluating writing, arithmetic and reading considering age, school years and school type.

Social Skills Rating System - SSRS-BR, Brazilian adaptation (Bandeira et al., 2009) of the reporting instrument of SS, academic competence and behavior problems (Gresham \& Elliott, 1990) presenting forms to be answered by children, teachers and parents (the latter not used in this study). Student form of the SS subscale included six factors: responsibility; empathy; assertiveness; selfcontrol; problem avoidance; expression of positive feelings. The teacher form included five factors: responsibility/ cooperation; positive assertion; self-control; self-defense and peer cooperation. The subscale academic competence ranks the student by comparing him to the others in classroom according to five categories: ranging from the $10 \%$ worst to the $10 \%$ best (Bandeira et al., 2009). Subscale of behavior problems was not used in the present study as the design of the study focused on adaptive aspects of social skills.

During the data collection period of this research, only the first version of the instrument had been validated using the Principal Components method and presented adequate psychometric indicators of construct validity, criterion validity based on contrasting groups, predictive validity, experimental validity, correlation with other psychological constructs, internal consistency (student form: global 0.78, the components between 0.46 and 0.62 Cronbach's Alpha; teacher form: global 0.94, the components between 0.73 and 0.92 Cronbach's Alpha) and temporal stability (student form: $r=0.78, p<0.001$ in the global scale and $r=0.44$ to $r=0.56, p<0.001$ in the composing subscales; teacher form: $r=0.71, p<0.001$ in the global scale and $r=0.49$ to
$0.77, p<0.001$ in the composing subscales). The subscale academic competence showed the internal consistency with a Cronbach's Alpha of 0.98 and the temporal stability showed a significant and positive correlation of test retest $(r=0.73$, $p<0.001$ ) (Bandeira et al.,2009).

Freitas and Del Prette (2015) performed a second validation by Principal Axis Factoring (PAF), with subsequent Confirmatory Factor Analysis, which is a more recommended method, resulting in a new version called $S S R S-B R 2$. In this version, several items were excluded due to low saturation coefficient and there was a reduction in the number of factors (teacher form: slight variations of teacher $\alpha=91$, eigenvalues between 1.17 and 9.29, explaining $61.46 \%$ of the variance, composed of: responsibility, selfcontrol, assertiveness/social confidence and affectivity; student form: slight variations $\alpha=73$ eigenvalues between 1.29 and 3.43 , explaining $36.96 \%$ of the data composed of the following factors: empathy/affectivity, responsibility, self-control/civility and assertiveness.

\section{Intervention}

The intervention was held with all children from each one of the three classes in one of the schools (77 students), out of which 21 students with consent constituted the IG. The intervention consisted of a 50-minute meeting per week, for each class, in a total of nine weeks. The activities of ER strategies were performed during school hours, making it possible to experience typical school situations.

The intervention focusing on strategies for ER was based on research developed in schools in Philadelphia, USA (Shure \& Spivack, 1982) which has used the cognitive interpersonal problem solving approach through lessons that help children solving problems regarding relationships. The lessons composed the book I Can Problem Solve (ICPS): an interpersonal cognitive problem solving program for children (Shure, 2006). The current study used 16 out of 60 ICPS lessons, due to their objectives of stimulating perception of emotions, vocabulary related to emotion expression and emotional regulation. The chosen lessons addressed joy (happy), sadness (sad), anger, fear, pride, frustration, impatience, concern, relief and love. Each emotional state was discussed in relation to its concept, the context in which it appeared, its typical expressing ways (physiological and somatic manifestations, behavioral and facial expressions), recognition of the emotion on yourself and in others, ways of regulating emotions and searching for strategies to solve situations caused by this emotion (ways and possible ER strategies), and development of empathy and collaborative behavior. The ICPS lessons were complemented by cognitive behavioral therapy exercises and techniques (Stallard, 2007) and by SS training (Del Prette \& Del Prette, 2011). 


\section{Data Analysis}

The statistics program SPSS version 15.0 for Windows was used in the data analysis. In all statistical analysis the significance level considered was 0.05 . A descriptive analysis of the continuous variables was done using measures of central tendency and variability. For the discrete variables, frequency distribution tables were designed. To compare intervention and comparison group the Pearson's
Chi-square test or the Fisher's exact test in the comparison of categorical variables and the non-parametric Mann-Whitney test in the analysis of continuous variables were used. The non-parametric tests were chosen due to the asymmetrical characteristic of the analyzed variables, as well as to the sample size. To compare the analyzed variables in the two moments of the research (paired data), the Wilcoxon tests were used to the continuous variables.

\section{RESULTS}

School achievement and academic competence were similar among children of CG and IG at the beginning of the study. At $2^{\text {nd }}$ evaluation, school achievement had improved similarly for children in both schools, although academic competence evaluated by the teachers was not better.

Teacher's evaluation of student's SS (Table 2) showed that CG had significantly better results for all aspects of SS at $1^{\text {st }}$ evaluation. After intervention there was a statistically significant improvement in IG whose results become equated to the results of CG. The only significant difference throughout time in the CG was a decrease in the students' scores of self-control.

The perception the children from each group have of their own SS did not change significantly throughout time, in any of the aspects (Table 3). Student self-evaluation of SS showed that the ones in CG had significantly better results related to global aspects of SS and also to responsibility, assertiveness and problem avoidance (Table 3 ) at $1^{\text {st }}$.

Table 2

Comparison of teachers' evaluation of social skills (SSRS-BR) of students submitted (IG) or non-submitted (CG) to the intervention focused on ER at $1^{\text {st }}$ and $2^{\text {nd }}$ evaluations

\begin{tabular}{|c|c|c|c|c|c|c|}
\hline \multirow{2}{*}{ Teacher's Evaluation } & \multicolumn{2}{|c|}{$1^{\text {st. }}$ evaluation } & \multicolumn{2}{|c|}{$2^{\text {nd. }}$ Evaluation } & \multirow{2}{*}{ p-value ${ }^{2}$} & \multirow{2}{*}{ p-value } \\
\hline & IG (21) & CG (35) & IG (18) & CG (34) & & \\
\hline \multicolumn{7}{|l|}{ Global Score - } \\
\hline Mean (Standard deviation) & $36.1(9.9)$ & $44.2(14.3)$ & $45.5(10.2)$ & $41.1(10.6)$ & 0.001 & 0.080 \\
\hline p-value ${ }^{1}$ & \multicolumn{2}{|c|}{0.011} & \multicolumn{2}{|c|}{0.249} & & \\
\hline \multicolumn{7}{|l|}{ Responsibility } \\
\hline Mean (Standard deviation) & $20.3(6.7)$ & $23.7(7.1)$ & $24.7(5.4)$ & $23.3(5.0)$ & 0.003 & 0.232 \\
\hline p-value ${ }^{1}$ & \multicolumn{2}{|c|}{0.048} & \multicolumn{2}{|c|}{0.333} & & \\
\hline \multicolumn{7}{|l|}{ Positive Assertion } \\
\hline Mean (Standard deviation) & $10.4(3.2)$ & $12.6(4.8)$ & $12.9(3.7)$ & $11.6(3.6)$ & 0.009 & 0.259 \\
\hline p-value ${ }^{1}$ & \multicolumn{2}{|c|}{0.034} & \multicolumn{2}{|c|}{0.404} & & \\
\hline \multicolumn{7}{|l|}{ Self-Control } \\
\hline Mean (Standard deviation) & $9.7(3.5)$ & $13.3(4.1)$ & $13.6(3.3)$ & $10.6(5.1)$ & 0.001 & 0.042 \\
\hline p-value ${ }^{1}$ & \multicolumn{2}{|c|}{0.007} & \multicolumn{2}{|c|}{0.074} & & \\
\hline \multicolumn{7}{|l|}{ Self-defense } \\
\hline Mean (Standard deviation) & $2.2(1.1)$ & $4.0(18)$ & $3.7(1.5)$ & $3.7(1.6)$ & 0.003 & 0.194 \\
\hline p-value ${ }^{1}$ & \multicolumn{2}{|c|}{$<0.001$} & \multicolumn{2}{|c|}{0.907} & & \\
\hline \multicolumn{7}{|l|}{ Peer cooperation } \\
\hline Mean (Standard deviation) & $4.3(1.6)$ & $5.6(2.2)$ & $5.5(1.6)$ & $4.7(2.0)$ & 0.014 & 0.356 \\
\hline p-value ${ }^{1}$ & \multicolumn{2}{|c|}{0.026} & \multicolumn{2}{|c|}{0.290} & & \\
\hline
\end{tabular}

Note. ${ }^{1}$ Comparison between IG and CG in each evaluation (Mann-Whitney Test)

${ }^{2}$ Comparison between $1^{\text {st }}$ and $2^{\text {nd }}$ evaluations for IG (Wilcoxon Test)

${ }^{3}$ Comparison between $1^{\text {st }}$ and $2^{\text {nd }}$ evaluations for CG (Wilcoxon Test) 
Comparison of social skills self-evaluation (SSRS-BR) by students submitted (IG) or non-submitted (CG) to the intervention focused on ER at $1^{\text {st }}$ and $2^{\text {nd }}$ evaluations.

\begin{tabular}{|c|c|c|c|c|c|c|}
\hline \multirow{2}{*}{ Self-Evaluation } & \multicolumn{2}{|c|}{$1^{\text {st }}$ evaluation } & \multicolumn{2}{|c|}{$2^{\text {nd }}$. evaluation } & \multirow{2}{*}{ p-value ${ }^{2}$} & \multirow{2}{*}{ p-value ${ }^{3}$} \\
\hline & IG (21) & CG (35) & IG (18) & CG (34) & & \\
\hline & IG (21) & CG (35) & IG (18) & CG (34) & & \\
\hline \multicolumn{7}{|l|}{ Global Score } \\
\hline Mean (Standard deviation) & $33.3(6.1)$ & $37.5(6.0)$ & $33.9(7.4)$ & $37.9(5.8)$ & 0.962 & 0.869 \\
\hline p-value ${ }^{1}$ & \multicolumn{2}{|c|}{0.017} & \multicolumn{2}{|c|}{0.038} & & \\
\hline \multicolumn{7}{|l|}{ Responsibility } \\
\hline Mean (Standard deviation) & $10.3(2.3)$ & $11.6(2.1)$ & $9.9(2.5)$ & $11.7(1.9)$ & 0.751 & 0.873 \\
\hline p-value ${ }^{1}$ & \multicolumn{2}{|c|}{0.032} & \multicolumn{2}{|c|}{0.019} & & \\
\hline \multicolumn{7}{|l|}{ Empathy } \\
\hline Mean (Standard deviation) & $4.5(2.0)$ & $4.9(1.1)$ & $5.1(1.6)$ & $5.0(1.5)$ & 0.339 & 0.410 \\
\hline p-value ${ }^{1}$ & \multicolumn{2}{|c|}{0.569} & \multicolumn{2}{|c|}{0.785} & & \\
\hline \multicolumn{7}{|l|}{ Assertiveness } \\
\hline Mean (Standard deviation) & $8.0(2.1)$ & $9.9(2.3)$ & $8.6(2.7)$ & $9.9(2.4)$ & 0.815 & 0.945 \\
\hline p-value ${ }^{1}$ & \multicolumn{2}{|c|}{0.006} & \multicolumn{2}{|c|}{0.093} & & \\
\hline \multicolumn{7}{|l|}{ Self-Control } \\
\hline Mean (Standard deviation) & $5.1(1.4)$ & $5.7(1.6)$ & $5.1(1.8)$ & $6.2(1.4)$ & 0.713 & 0.285 \\
\hline p-value ${ }^{1}$ & \multicolumn{2}{|c|}{0.140} & \multicolumn{2}{|c|}{0.033} & & \\
\hline \multicolumn{7}{|l|}{ Problems Avoidance } \\
\hline Mean (Standard deviation) & $4.6(1.7)$ & $7.0(1.9)$ & $5.4(1.8)$ & $6.5(1.6)$ & 0.441 & 0.048 \\
\hline p-value ${ }^{1}$ & \multicolumn{2}{|c|}{$<0.001$} & \multicolumn{2}{|c|}{0.073} & & \\
\hline \multicolumn{7}{|c|}{ Expression of positive feelings } \\
\hline Mean (Standard deviation) & $6.0(1.9)$ & $6.3(1.8)$ & $6.0(1.2)$ & $5.9(1.7)$ & 0.896 & 0.298 \\
\hline p-value ${ }^{1}$ & \multicolumn{2}{|c|}{0.523} & \multicolumn{2}{|c|}{0.851} & & \\
\hline
\end{tabular}

Note. ${ }^{1}$ Comparison between IG and CG in each evaluation ( Mann-Whitney Test)

${ }^{2}$ Comparison between $1^{\text {st }}$ and $2^{\text {nd }}$ evaluations for IG (Wilcoxon Test)

${ }^{3}$ Comparison between $1^{\text {st }}$ and $2^{\text {nd }}$ evaluations for CG (Wilcoxon Test)

evaluation. After intervention ( $2^{\text {nd }}$ evaluation), results related to assertiveness and problem avoidance in children of IG became similar to the ones in CG but global aspects of SS and responsibility did not improve. Despite self-control evaluated by children was not significantly different at $1^{\text {st }}$ evaluation neither throughout time, children of CG scored better in comparison to IG according to results of their self-control at $2^{\text {nd }}$ evaluation. Student self-evaluation of SS related to empathy, and expression of positive feelings (Table 3) were similar for both groups in both evaluations.

\section{DISCUSSION}

Previous to intervention, at $1^{\text {st }}$ evaluation, all aspects of teacher's evaluation of student's SS and the global score, responsibility, assertion and problem avoidance aspects in student self-evaluation of SS showed inferior results among children of the IG. Such result was not expected, since both schools equated on socioeconomic and cultural indexes.

Parents relationship was the only data with significant difference between the groups. Although CG has a higher percentage of separated/divorced parents, students in this group obtained better initial results in SS. The hypothesis of association between separation of parents with negative influence in children's social skills has not been confirmed by some studies. According to Leme et al. (2015) the separation of parents can result in changes in social support from family members, which can modify spousal, parent-child and intra-sibling interaction, but the quality of this change depends on the complex interplay between internal and external personal resources available to the family members. On the other hand, the previous presence of good SS can contribute to more affectionate, positive and reciprocal parent-child interactions. It may also impede the emergence of interpersonal relations based on aggressiveness and/or passiveness in the context 
of separation which could provide lower levels of social support appraisals from family.

Leme et al. (2015) point out that, more than family arrangement, the form of family interaction has more impact on the social repertoire of children. Although not significant $(p=0.055)$, results of family atmosphere in this study are in agreement with that proposition as CG, who obtained better initial results, declared family harmony more frequently, while GI pointed out a higher level of disturbance in the family climate.

The power of intergenerational transmission (Boutwell \& Beaver, 2010; Comodo et al., 2017) has also been studied in the field of socioemotional behaviors and several children's SS factors have been correlated with parents' low selfcontrol and expression of positive feelings.

It is known that a more favorable social and economic context offers greater chances of appropriate social development and socialization (Bandeira et al., 2006; Campos et al., 2018). In contrast, vulnerable and stressing environment reduces the individual's ability to manage their negative emotions (Gallo \& Matthews, 2003; Moreira et al., 2012). Although significant differences in family income have not been found when comparing both schools samples, there may be a difference in social issues, which characterize the regions where IG and CG schools are located. Data that could support this hypothesis is that the majority of IG parents informed living in the outskirts, whereas in CG, there was a more homogeneous distribution of the answers that indicated residence as being outskirts neighborhood or metropolitan region neighborhood. This difference of view may be related to the fact that IG school is close to housing complexes, recently built for accommodating families expropriated from areas of irregular occupation, constituting a region more associated with urban violence and lack of access to citizens' rights when compared to the region where CG lives.

Self-evaluations results kept the initial difference in global score of SS and in responsibility aspect, but indicated that IG overcame the initial difference related to $C G$ regarding assertiveness and problem avoidance aspects. In the $C G$, who were not submitted to intervention focused on ER strategies, student self-evaluation of SS did not agree with teachers' evaluation, since the first one suggested improvement in self-control and the latter indicated a worsening of this aspect of SS. The inconsistencies found on the self-evaluation results might be due to the lower reliability results on student form, suggesting that selfassessment of SS and social competence by children is usually less accurate compared to the evaluation by other informants (Freitas \& Del Prette, 2015). This is also found in other validation studies reported in literature (Barreto et al., 2011; Freitas et al., 2016; Freitas \& Del Prette 2010; Gresham et al., 2010). Despite Bandeira et al. (2009) do not specify the values for each factor, it is known that an internal consistency of SSRS-BR student form is between 0.46 and
0.62. Considering SSRS-BR2 version, student form values were lower, including self-control (empathy/affectivity $=52$, responsibility $=58$, self-control/civility $=49$, assertiveness $=34$ ), while teacher form values (responsibility $=0.91$, self-control $=85$, assertiveness $/$ social confidence $=80$, cooperation/affectivity $=86$ ) were ideally above 60 .

According to teacher's evaluation of students, all aspects of SS improved in the IG, after intervention focused on ER strategies. The inferior results at $1^{\text {st }}$ evaluation became equivalent to those of $\mathrm{CG}$ at $2^{\text {nd }}$ evaluation. It was also noticed that self-control of students in CG, evaluated by teachers, had significant reduction. These data may suggest a change in the way teachers evaluated students. But it can also indicate that intervention on ER can bring benefits to SS aspects, acting in a protective way on the development of abilities related to ER and SS, as hypothesized by the present study and corroborated by suggestions of others.

Data related to SS are interesting, although we may not establish a cause-effect relationship between the intervention focused on ER and observed results, since this relationship should be better investigated and replicated to overcome the limitations identified in the present study. Nevertheless, the results meet DET and SEL logic model suggesting that ER ability correlates to SS, to popularity and to adjustment and adaptation to environment (Eisenberg et al., 2000; Eisenberg et al., 2004). According to Panayiotou et al. (2019), the link between social-emotional competence and school connectedness is particularly important, as it is positively associated with adaptive outcomes and negatively correlated with outcomes of mental health difficulties, social rejection, and school problems. This justifies the fact that emotionally competent children likely feel more comfortable in the school environment due to their ability to control their emotions, and may achieve greater academic outcomes because they are better at initiating, sustaining, and regulating their motivation for goals directed to learning. On the other hand, those with poor emotional skills are at risk for emotional distress and frustration, which can lead to disengagement.

Intervention on ER did not affect students' school achievement. Although TDE results improved significantly throughout time, there was no significant difference between CG and IG. This suggests that teaching offered by both schools produces similar results. Also students' academic competence, evaluated by teachers, has not changed neither along time nor after intervention.

Literature proposes that children with abilities in regulating emotions would have better chances of succeeding in the first stages of academic development, whereas children with emotional difficulties would have a higher risk of having their school performance jeopardized by influence of poor adaptive emotions (Eisenberg et al., 2005; Raver, 2003). This would happen because inefficiency in physiologically controlling emotions may inhibit the use of cognitive processes by children, impairing their skills of 
working memory, attention and planning. This way, retention of school contents, productivity and accuracy in performing activities would be below the expected for that individual (Blair, 2002; Graziano et al., 2007).

A longitudinal study (Panayiotou et al., 2019) proposed an integrative model to explain how social-emotional competence interacts over time to contribute to future academic achievement. The model suggests that it is not the improvement of social-emotional competence by itself that positively influences later academic performance, but its intermediate impact on mental health difficulties. These findings corroborate results of the present study and of others previous ones in literature, which indicates that interventions on SS and ER act as a protective factor and set the precedent for the later positive developmental outcomes.

Some factors might have interfered in the results of this study and should be considered: a) small sample size; b) total number and frequency of intervention meetings may have been insufficient for the expected impact; c) intervention program could use a larger number of techniques and experiences of ER and SS development targeted to academic skills; d) control level of intervention aspects and strictness on monitoring teachers' actions related to the intervention could be higher (CASEL, 2013; Del Prette,\& Del Prette, 2011; Domitrovich \& Greenberg, 2000); e) age group selected for the study, considering that in the beginning of schooling, children's school achievement might be influenced by factors other than just regulation of emotions and SS, such as previous family stimulation; f) two months-period of latency between the intervention and the second evaluation that coincided with school holidays, which prevented the more frequent use of intervention techniques in school context.

Intervention Group and Comparison Group were not developed in both schools because, if they were done at the same time children and teachers submitted to the intervention program could share their new skills with their peers in Comparison Group, confounding the results observed for this group. Undoubtedly further studies must be conducted to provide a better comparison of the effectiveness of the intervention focused on ER strategies. The potential benefits of developing ER and SS in school context by means of early interventions aiming a healthy development of children's cognition and better school achievement justifies these investigations.

Ethical approval: "All procedures performed in studies involving human participants were in accordance with the ethical standards of the institutional and/or national research committee and with the 1964 Helsinki declaration and its later amendments or comparable ethical standards."

\section{REFERENCES}

Angelini, A. L., Alves, I. C. B., Custódio, E. M, Duarte, W. F., \& Duarte, J. L. M. (1999). Matrizes progressivas coloridas de Raven: Escala especial. Manual [Raven's colored progressive matrices: Special range. Manuals]. CETEPP.

Bandeira, D. R., Alves, I. C. B., Giacomel, A. E., \&Lorenzatto, L. (2004). Matrizes progressivas coloridas de Raven - escala especial: normas para Porto Alegre, RS [The Raven's coloured progressive matrices: norms for Porto Alegre, RS]. Psicologia em Estudo,9 (3), 479-486. https://doi.org/10.1590/S141373722004000300016

Bandeira, M., Del Prette, Z. A. P., Del Prette, A., \& Magalhães, T. (2009).Validação das escalas de habilidades sociais, comportamentos problemáticos e competência acadêmica (SSRS-BR) para o ensino fundamental [Validating scales of social skills, behavior problems and academic competence (SSRS-BR) for elementary school]. Psicologia: Teoria e Pesquisa,25(2), 271-282. https://doi.org/10.1590/S010237722009000200016

Bandeira, M. R., Rocha, S. S., Freitas, L. C., Del Prette, Z. A P., \& Del Prette, A. (2006). Habilidades sociais e variáveis sociodemográficas em estudantes do ensino fundamental [Social skills and sociodemographic variables in elementary school students]. Psicologia em Estudo - Maringá,11(3), 541-549. https://doi.org/10.1590/S1413-73722006000300010

Barreto, S. O., Freitas, L. C., \& Del Prette, Z. A. P. (2011). Habilidades sociais na comorbidade entre dificuldades de aprendizagem e problemas de comportamento: uma avaliação multimodal [Social skills in the comorbidity between learning disabilities and behavior problems: a multimodal assessment]. Psico, PUC-RS, 42(4), 503-510.
Blair, C. (2002). School readiness. Integrating cognition and emotion in a neurobiological conceptualization of children's functioning at school entry. American Psychologist, 57(2), 111-127. https://doi.org/10.1037//0003-066x.57.2.111

Boutwell, B. B., \& Beaver, K. M. (2010). The intergenerational transmission of low self-control. Journal of Research in Crime and Delinquency, 47(2), 174-209. https://doi. org/10.1177/0022427809357715

Bywater, T., Hutchings, J., Whitaker, C., Evans, C., \& Parry, L. (2011). The incredible years therapeutic dinosaur programme to build social and emotional competence in welsh primary schools: Study protocol for a randomized controlled trial. Trials, 12(39). https://doi.org/10.1186/1745-6215-12-39

Campos, J. R., Del Prette, Z. A. P.,\& Del Prette, A. (2018). Relações entre depressão, habilidades sociais, sexo e nível socioeconômico em grandes amostras de adolescentes [Relating depression, social skills, sex and socioeconomic status in large samples of adolescentes]. Psicologia: Teoria e Pesquisa, 34(e3446) 1-10. https://doi.org/10.1590/0102.3772e3446

Collaborative for Academic, Social, and Emotional Learning (2013). Guide: Effective social and emotional learning programs. Preschool and elementary school edition. CASEL.

Collaborative for Academic, Social, and Emotional Learning. (n.d). History. https://casel.org/history/

Chernyshenko, O. S., Kankaraš, M., \& Drasgow, F. (2018). Social and emotional skills for student success and well-being: conceptual framework for the OECD study on social and emotional skills. [OECD Education Working Papers, No. 173]. OECD Publishing. https://doi.org/10.1787/db1d8e59-en.

Comodo, C. N., Del Prette, A., \& Del Prette, Z. A. P. (2017). Intergeracionalidade das habilidades sociais entre pais e filhos 
adolescentes [Intergenarational transmission of social skills between parents and adolescent children]. Psicologia: Teoria e Pesquisa,33, e33311.https://doi.org/10.1590/0102.3772e33311

Damásio, A. R. (2011) Self comes tomind: constructing the conscious brain. Pantheon Books.

Del Prette, Z. A. P.,\& Del Prette, A. (2009). Psicologia das habilidades sociais: diversidade teórica e suas implicações [Psychology of social skills: theoretical diversity and its implications]. Vozes.

Del Prette, Z. A. P., \& Del Prette, A. (2011) Psicologia das habilidades sociais na infância: teoria e prática [Psychology of social skills in childhood: theory and practice] (5nd. ed.). Vozes.

Domitrovich, C. E., \& Greenberg, M. T. (2000). The study of implementation: current findings from effective programs that prevent mental disorders in school-aged children. Journal of Educational and Psychological Consultation,11(2), 193-221. https://doi.org/10.1207/S1532768XJEPC1102_04

Domitrovich, C. E., Durlak, J. A., Staley, K. C., \& Weissberg, R. P. (2017). Social-emotional competence: an essential factor for promoting positive adjustment and reducing risk in school children. Child Development, 88(2), 408-416. https://doi. org/10.1111/cdev.12739

Dowd, T.,\& Tierney, J. (2005). Teaching social to youth: a step-bystep guide to 182 basic to complex skills plus helpful teaching techniques (2nd ed.). Boys Town Press.

Eisenberg, N., Fabes, R. A., Guthrie, I. K., \&Reiser, M. (2000). Dispositional emotionality and regulation: Their role in predicting quality of social functioning. Journal of Personality and Social Psychology, 78(1), 136-157. https:// doi.org/10.1037//0022-3514.78.1.136

Eisenberg, N., Sadovsky, A., \& Spinrad, T. L. (2005). Associations of emotion-related regulation with language skills, emotion knowledge, and academic outcomes. New Directions for Child and Adolescent Development, 109, 109-118.

Eisenberg, N., Smith, C. L., \& Spinrad, T. L. (2004). Effortful control: Relations with emotion regulation, adjustment, and socialization in childhood. In R. F.Baumeister, \& D. Vohs (Eds.), Handbook of self-regulation: research, theory, and applications (2nd ed., pp. 259-282). Guilford Press.

Faria, A. M., Kendziora, K., Brown, L., O’Brien, B., \& Osher, D. (2013). PATHS Implementation and outcome study in the Cleveland Metropolitan School District: Final Report. American Institutes for Research. https:/www.air.org/sites/ default/files/downloads/report/Evaluation of PATHS in CMSD final report 62413 0.pdf

Freitas, L. C., \& Del Prette, Z. A. P. (2010). Comparando autoavaliação e avaliação de professores sobre as habilidades sociais de crianças com deficiência mental [Comparing selfassessment and teacher evaluation on the social skills of children with mental disabilities]. Interpersona: A International Journal on Personal Relationships, 4(2), 183-193.

Freitas, L. C., \& Del Prette, Z. A. P. (2015). Social Skills Rating System - Brazilian version: new exploratory and confirmatory factorial analyses. Avances em Psicología Latinoamericana, 33(1), 135-156. https://doi.org/10.12804/apl33.01.2015.10

Freitas, L. C., Bandeira, M., Del Prette, A., \& Del Prette, Z. A. P. (2016).Comparando indicadores psicométricos de duas versões brasileiras do Social Skills Rating System: Uma revisão da literatura [Comparing psychometric indicators of two brazilian versions of the social skills rating system: A literature review]. Psico-USF, 21(1),25-36.

Gallo, L. C., \& Matthews, K. A. (2003). Understanding the association between socioeconomic status and physical health: do negative emotions play a role? Psychological Bulletin, 129(1), 10-51. https://doi.org/10.1037/00332909.129.1.10

Graziano, P. A., Reavis, R. D., Keane, S. P., \& Calkins, S.D. (2007). The role of emotion regulation in children's early academic success. Journal of School Psychology, 45(1), 3-19. https:// doi.org/10.1016/j.jsp.2006.09.002

Gresham, F. M., \& Elliott, S. N. (1990). Social skills rating system. American Guidance Service.

Gresham, F. M., Elliott, S. N., Cook, C. R., Vance, M. J., \& Kettler, R. (2010). Cross-informant agreement for ratings for social skill and problem behavior ratings: An investigation of the social skills improvement system-rating scales. Psychological Assessment, 22(1), 157-166. https://doi.org/10.1037/a0018124

Gross, J. J. (2007). Handbook of emotional regulation. The Guilford Press.

Hawkins, J. D., Kosterman, R., Catalano, R. F, Hill, K. G., \& Abbott, R.D. (2008). Effects of social development intervention in childhood 15 years later. Archives of Pediatrics\& Adolescent Medicine,162(12), 1133-1141. https://doi.org/10.1001/ archpedi.162.12.1133.

Izard, C. E., Fine, S., Mostow, A., Trentacosta, C., \& Campbell, J. (2002). Emotion processes in normal and abnormal development and preventive intervention. Development and Psychopathology, 14(4),761-787. https://doi.org/10.1017/ S0954579402004066

Kopp, C. B. (1989). Regulation of distress and negative emotions: a developmental view. Developmental Psychology, 25(3), 343354. https://doi.org/10.1037/0012-1649.25.3.343

Lasaitis, C. (2009). Aspectos afetivos e cognitivos da homofobia no contexto brasileiro: um estudo psicofisiológico [Affective and cognitive aspects of homophobia in Brazilian citizens A psychophysiological study] (Master dissertation). Escola Paulista de Medicina, Universidade Federal de São Paulo UNIFESP, São Paulo, SP, Brazil.

Lawson, G. M., McKenzie, M. E., Becker, K. D., Selby, L., \& Hoover, S. A. (2018). The core components of evidence-based social emotional learning programs. Prevention Science, 20(4), 457-467. https://doi.org/10.1007/s11121-018-0953-y

Leme, V. B. R., Del Prette, Z. A. P., \& Coimbra, S. (2015). Social skills, social support and well-being in adolescents of different family configurations. Paidéia (Ribeirão Preto), 25(60), 9-17. https://doi.org/10.1590/1982-43272560201503

Martin, R. E. \& Ochsner, K. N. (2016). The neuroscience of emotion regulation development: implications for education. Current Opinion in Behavioral Sciences, 10, 142-148. https://doi. org/10.1016/j.cobeha.2016.06.006

Ministério da Educação. Secretaria de Educação Básica (2018). Base Nacional Comum Curricular [Common National Curriculum Base]. MEC. http://basenacionalcomum.mec.gov.br/images/ BNCC EI EF 110518 versaofinal site.pdf

Mocaiber, I., Öliveira. L., Pereira, M. G., Machado-Pinheiro, W., Ventura, P. R., Figueira, I. V., \& Volchan, E. (2008). Neurobiologia da regulação emocional: implicações para a terapia cognitivo-comportamental [Neurobiology of emotion regulation: implications for cognitive-behavioral therapy]. Psicologia em Estudo, 13(3), 531-538.

Moreira, P. L., Abreu, E., \& Rique-Neto, J. (2012). Influência da idade e do contexto socioeducacional na compreensão emocional de crianças [Age and socio-educational effects on children's emotional understanding]. Estudos de Psicologia (Campinas), 29, 761-767. https://doi.org/10.1590/S0103166X2012000500012

Panayiotou, M., Humphrey, N., Wigelsworth, M. (2019). An empirical basis for linking social and emotional learning to academic performance. Contemporary Educational Psychology, 56, 193-204. https://doi.org/10.1016/j.cedpsych.2019.01.009

Raver, C. C. (2003). Young children's emotional development and school readiness. Eric Digest. http://files.eric.ed.gov/fulltext/ ED477641.pdf

Riggs, N. R., Greenberg, M. T., Kusché, C. A., \&Pentz, M. A. (2006). The mediational role of neurocognition in the 
behavioral outcomes of a social-emotional prevention program in elementary school students: effects of the PATHS curriculum. Prevention Science, 7(1), 91-102. https://doi.org/10.1007/ s11121-005-0022-1

Riquelme, E., \& Munita, F. (2011). La lectura mediada de literatura infantil como herramientapara laalfabetización emocional [The mediated reading of child literature as a tool for the basic emotional literacy]. Estudios Pedagógicos, 37(1), 269-277. https://doi.org/10.4067/S0718-07052011000100015

Rodrigues, M. C., Dias, J. P., \& Freitas, M. F. R. L. (2010). Resolução de problemas interpessoais: promovendo o desenvolvimento sociocognitivo na escola [Solving interpersonal problems: promoting sociocognitive development in school]. Psicologia em Estudo (Maringá), 15(4), 831-839.

Shonkoff, J. P. (2011). Protecting brains, not simply stimulating minds. Science, 333(6045), 982-983. https://doi.org/10.1126/ science. 1206014

Shure, M. B., \&Spivack, G. (1982). Interpersonal problem-solving in young children: a cognitive approach to prevention. American Journal of Community Psychology, 10(3), 341-356. https://doi.org/10.1007/BF00896500

Shure, M. B.(2006). Eu posso resolver problemas: educação infantil e ensino fundamental: um programa de solução cognitiva para problemas interpessoais [I can solve problems: early childhood education and elementary school: a cognitive solution program for interpersonal problems]. Vozes.

Stallard, P. (2007) Guia do terapeuta para bons pensamentos - bons sentimentos: utilizando a terapia cognitivo comportamental com crianças e adolescentes [Therapist's guide to good thoughts - good feelings: using cognitive behavioral therapy with children and adolescentes]. Porto Alegre: Artmed.

Stein, L. M. (1994). TDE: Teste de Desempenho Escolar: manual para aplicação e interpretação [School Performance Test: manual for application and interpretation]. Casa do Psicólogo.

Taylor, R. D., Oberle, E., Durlak, J. A., \& Weissberg, R. P. (2017). Promoting positive youth development through school-based social and emotional learning interventions: a meta-analysis of follow-up effects. Child Development, 88(4), 1156-1171. https://doi.org/10.1111/cdev.12864

Todos pela Educação. (2019). Anuário Brasileiro da Educação Básica 2019 [Brazilian Yearbook of Basic Education 2019]. Ed. Moderna. https://www.todospelaeducacao.org.br/_uploads/_ posts/302.pdf

World Health Organization (2003). Creating an environment for emotional and social well-being: an important responsibility of a Health Promoting and Child Friendly School. WHO information series on school health. Document ten. Geneva: WHO. https://www.who.int/school_youth_health/media/en/ sch_childfriendly_03_v2.pdf?ua $=1$

Wyman, P. A., Cross, W., Brown.C.H., Yu, Q., Tu, X., \&Eberly, S. (2010). Intervention to strengthen emotional self-regulation in children with emerging mental health problems: proximal impact on school behavior. Journal of Abnormal. Child Psychology, 38(5), 707-720. https://doi.org/10.1007/s10802010-9398-x 